\title{
Analysis of Strategies to Reduce Air Pollution from Vessels: A Case for the Strait of Istanbul
}

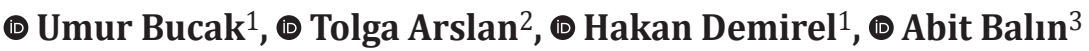 \\ ${ }^{1}$ Zonguldak Bülent Ecevit University Faculty of Maritime, Department of Maritime Business Management, Zonguldak, Turkey \\ ${ }^{2}$ Med Marine Company, Zonguldak, Turkey \\ ${ }^{3}$ Istanbul University School of Transportation and Logistics, Istanbul, Turkey
}

\begin{abstract}
Air pollution that stems from vessels has become a critical problem especially for people living in cities with heavy maritime traffic. Istanbul City is an important metropolis of the region and the world. This study proposed strategies to reduce air pollution in the Strait of Istanbul by extending the International Maritime Organization and European Union strategies' scope. The strategies' priority levels were analyzed employing the fuzzy analytical hierarchy process method by asking opinions from experts who live in the Strait of Istanbul as a marine pilot or vessel traffic operator with at least 10 years of existing work experience. The analysis results determined which types of ship that passes the strait are more sensitive to the above mentioned strategies using the fuzzy technique for order preference by similarity to ideal solution method. Accordingly, the strategies under the "Declaration of the Strait of Istanbul and the Marmara Sea as a Sulfur Emission Control Area" and "prohibition of the use of heavy fuel on ships" have been the highest priority strategies in reducing air pollution in the strait. The direct passing ships achieved the highest sensitivity level to the strategies held in this study according to the selected experts.
\end{abstract}

\section{Keywords}

Air pollution, Strait of Istanbul, Strategies, Fuzzy logic

\section{Introduction}

The industrial revolution, which was achieved using carbon dioxide $\left(\mathrm{CO}_{2}\right)$ producer fossil fuels as energy sources, has continuously increased production capacities with the products transported worldwide with the effect of globalization. The maritime transportation structure that is suitable for providing economies of scale ensures the transport of $80 \%-90 \%$ [1] of these products between ports. The effects of maritime transport on $\mathrm{CO}_{2}$ emissions were brought on the agenda in the 1980s. It is estimated that maritime accounts for approximately $43 \%$ of the total energy used in world transportation [2]. According to the reports published by the International Maritime Organization (IMO), $\mathrm{CO}_{2}$ emissions from vessels accounted for $2.6 \%$ of the total annual world $\mathrm{CO}_{2}$ emissions, whereas sulfur and nitrogen emissions from vessels accounted for $15 \%$ and $13 \%$, respectively. Moreover, $70 \%$ of the vessel emissions were reported to be generated in offshore areas closer than $400 \mathrm{~km}$ from land. For example, the emissions from shipping activities in Shanghai accounted for approximately $12 \%$ of the city's emissions [3]. Alternatively, according to the report, "Time for International Action on $\mathrm{CO}_{2}$ Emissions from Shipping," published by the European Union (EU) [4], $\mathrm{CO}_{2}$ emissions from maritime transportation can be doubled if no precautions are taken.

The efforts for preventing air pollution from shipping were first brought on the agenda by the Marine Environment Protection Committee (MEPC), an IMO subsidiary in 1988. The first step was implemented in May 2005 with the International Convention For The Prevention Of Pollution From Ships (MARPOL) Annex VI that imposed restrictions regarding the ship's emissions. These restrictions have increasingly become more compelling and stricter over the years. The last regulation "IMO 2020" requires the 
ship owners to either the switch type of fuel with a cleaner one $\left(0.5 \% \mathrm{SO}_{x^{\prime}}\right.$ very low sulfur fuel oil), or equip on board pollutant abatement (scrubber) systems [5]. To better illustrate the urgency of this regulation, a report in the IMO's $70^{\text {th }}$ session of the Marine Environment Protection Committee forecasts a $77 \%$ increase in sulfur emissions and 570,000 early deaths if these regulations, which came into force as of January 01, 2020, are postponed for five years [6]. Although these regulations are an important step toward reducing air pollution, difficulties in implementation, detection, and follow-up of this regulations bring some concerns. To overcome these concerns, supporting incentive activities, taking additional precautions, and carrying out regional-specific work are recommended.

Istanbul City has grown 6 times in population over the last 50 years and the city is an important metropolis of the region and the world. As in many megacities, air pollution is a critical problem for Istanbul City as well. According to the report published by the Republic of Turkey Ministry of Environment and Urban Development in 2017, gas emissions in Istanbul City are above the desired limits. The main sources of air pollution in Istanbul City are the vehicles and industrial emissions [7]. In addition to the heavy urban land traffic, dense maritime activities owing to the location of the city connecting the continents contribute significantly to the production of these emissions. Maritime transport activities in Istanbul City can be classified as the following: (1) vessels stopped over in ports, (2) vessels passing without stopover, and (3) local maritime traffic. Istanbul City has 16 port facilities that are frequently visited by ships [8]. According to the Maritime Trade Statistics Report published by the Republic of Turkey Ministry of Transportation and Infrastructure [9], 6472 ships visited these ports in 2018. In addition to the international maritime vessel traffic, ferry services in this region carried $114,235,943$ passengers in 2018. Moreover, the Strait of Istanbul, which is 17 nautical miles long and has an average of 55,000 ships passing every year, is a unique waterway in the region. Approximately 150 ships pass through the Strait of Istanbul every day, of which 27-28 ships carry dangerous goods. Furthermore, the Strait of Istanbul has 2500 local maritime traffic that transports approximately 2,000,000 people. Besides the physical, oceanographic, and meteorological elements that restrict the safety sailing in the strait, the Strait of Istanbul is four times denser than the Panama Canal (in terms of the number of ships passing) and has three times heavier traffic than Suez Canal [10]. The negative contribution to air pollution of the ships passing through the Strait of Istanbul accounts for approximately $10 \%$ of the total air pollution in this geography [11]. The annual estimation of ship emissions in the strait comprises 7295.5 tons of $\mathrm{NO}_{\mathrm{x}}$ and 6062.5 tons of $\mathrm{SO}_{2}$ [12].

Studies in the literature related to the emissions produced by the ships in the Strait of Istanbul have focused on detecting the amount of emissions and in developing strategies to reduce these emissions. Im et al. [13] determined the terrestrial and marine emissions in Istanbul City. Meanwhile, Kılıç [14] tried making annual emission estimates of merchant ships in the Marmara Sea, and Bayırhan et al. [11] measured the exhaust emissions of ships passing through the strait based on actual ship movements and ship machinery information. Alternatively, Dogrul et al. [12] evaluated the effects of gas emissions on the Strait of Istanbul according to various weather scenarios. To prevent marine-induced emissions in Istanbul City, Öztürk and Küçükgül [15] evaluated certain precautions to be taken against air pollution in the port areas and stated that the activity should be organized according to the principles of environmental management planning to minimize the environmental impacts of the ports. Further, the authors suggested that the environmental management activities should be carried out with a holistic approach throughout the ports. Han [16] proposed technical, operational, and market-based strategies to reduce air pollution from marine vessels and emphasized the importance of using these strategies together. Peksen and Alkan [17] estimated the gas emissions from the sea vehicles by comparing the conditions of the Marmara region, which is declared as an emission control area. The authors revealed the benefits of being an emission control area of the region to its air quality. Rață et al. [18] determined the air pollution from vessels navigating the Black Sea and the area that will most likely be affected. They proposed to use a higher quality of fuel to reduce sulfur emissions from marine vessels in coastal areas, to equip scrubbers to ships, and to restrict the ships' speeds within the limits of 200 nautical miles. Lastly, Tatar and Özer [19] revealed the carbon emissions from global shipping and suggested strategies such as improvement/development on the equipment, transition to renewable energy, and using ultralow sulfur content fuel to reduce carbon emissions.

This study developed strategies to reduce the emissions caused by marine vessels in Istanbul City, and the vessel types diversifying the service they offered were evaluated by considering their sensitivity levels to these strategies. In the following part of the study, the methods employed in the analyses were introduced and the application steps were explained. After, the problem was identified, the experts who were consulted were introduced, and the findings of the analyses were presented. In the conclusion, the results were interpreted and suggestions were made regarding the implementation of the prominent strategies. 


\section{Methodology}

The analytic hierarchy process (AHP) method is a multicriteria decision-making method that is widely used becuase it is easy to understand and use in both quantitative and qualitative data analyses. This method is based on subgrouping, pairwise comparisons, priority vector production, and syntheses [20]. The most important advantage of using this model is its specialty to transform the qualitative expressions of the experts to analyzable quantitative variables. However, the conventional AHP can fail to fully reflect human thoughts and is often criticized for this reason. Thus, the fuzzy AHP method has been developed to accommodate one's self to the indecisive nature of linguistic assessments [21] and to address the deficiencies of the traditional AHP method in reflecting human thoughts [22-24].

Linguistic variables are expressed in five basic terms whose values are in a natural or artificial language. These terms are the fuzzy five-level scale values: (1) absolutely important, (2) very strongly important, (3) essentially important, (4) weakly important, and (5) equally important [25]. Table 1 shows the linguistic equivalents of the fuzzy numbers. In this study, the preference levels of the preventive strategies against air pollution from vessels around the Strait of Istanbul based upon pairwise comparisons were evaluated via nine basic linguistic terms: (1) absolutely strong, (2) very strong, (3) fairly strong, (4) slightly strong, (5) equal, (6) slightly weak, (7) fairly weak, (8) very weak, and (9) absolutely weak. Table 2 shows the results derived from the preliminary analysis of the representation of each linguistic variable as a triangular fuzzy number (TFN) in the $0-9$ scale range.

Table 1. Triangular fuzzy conversion scale [21]

\begin{tabular}{|c|c|}
\hline Linguistic scale & TFNs/reciprocal TFNs \\
\hline AS-absolutely strong & $(3.50,4.00,4.50)$ \\
\hline VS-very strong & $(2.50,3.00,3.50)$ \\
\hline FS-fairly strong & $(1.50,2.00,2.50)$ \\
\hline SS-slightly strong & $(0.50,1.00,1.50)$ \\
\hline E-equal & $(1.00,1.00,1.00)$ \\
\hline SW-slightly weak & $(0.67,1.00,2.00)$ \\
\hline FW-fairly weak & $(0.40,0.50,0.67)$ \\
\hline VW-very weak & $(0.29,0.33,0.40)$ \\
\hline AW-absolutely weak & $(0.22,0.25,0.29)$ \\
\hline \multicolumn{2}{|c|}{ TFN: Triangular fuzzy number } \\
\hline
\end{tabular}

Table 2. Fuzzy evaluation scores for the alternatives [26]

\begin{tabular}{|c|c|}
\hline Linguistic terms & Fuzzy score \\
\hline Absolutely poor-AP & $(0.00,1.00,2.00)$ \\
\hline Very poor-VP & $(1.00,2.00,3.00)$ \\
\hline Poor-P & $(2.00,3.00,4.00)$ \\
\hline Medium poor-MP & $(3.00,4.00,5.00)$ \\
\hline Fair-F & $(4.00,5.00,6.00)$ \\
\hline Medium good-MG & $(5.00,6.00,7.00)$ \\
\hline Good-G & $(6.00,7.00,8.00)$ \\
\hline Very good-VG & $(7.00,8.00,9.00)$ \\
\hline Absolutely good-AG & $(8.00 .9 .00,9.00)$ \\
\hline
\end{tabular}

If $\mathrm{M}_{1}$ and $\mathrm{M}_{2}$ are considered TFNs, addition, multiplication, and inverse operations can be performed on the TFNs following the 3 equations below:

Addition: $\quad \mathrm{M}_{1} \oplus \mathrm{M}_{2}=\left(1_{1}+1_{2}, \mathrm{~m}_{1}+\mathrm{m}_{2}, \mathrm{u}_{1}+\mathrm{u}_{2}\right)$

Multiplication: $\mathrm{M}_{1} \otimes \mathrm{M}_{2}=\left(1_{1} \cdot 1_{2}, \mathrm{~m}_{1} \cdot \mathrm{m}_{2}, \mathrm{u}_{1} \cdot \mathrm{u}_{2}\right)$

Inverse: $\quad \mathrm{M}_{1}^{-1}=\left(1_{1}, \mathrm{~m}_{1}, \mathrm{u}_{1}\right)^{-1} \cdot\left(1 / \mathrm{u}_{1}, 1 / \mathrm{m}_{1}, 1 / 1_{1}\right)$

This study aims to analyze the efficiency level of the strategies that involve precautions against the air pollution generated from the vessels around the Strait of Istanbul on the selected vessel types using the fuzzy technique for order preference by similarity to ideal solution (TOPSIS) method. According to the TOPSIS concept, the most suitable alternative should have either the shortest distance from the positive ideal solution (PIS) or the farthest distance from the negative ideal solution (NIS) [27]. In this study, an extended fuzzy TOPSIS method similar to that applied by Hwang and Yoon [28] and Ertuğrul and Karakaşoğlu [29] was used. The application steps of the fuzzy AHP-TOPSIS hybrid method to be implemented in the study are as follows:

Step 1: A pairwise comparison matrix that comprises comparisons of each criterion in the hierarchy system was constituted. Formula 4 is below.

$$
\tilde{A}=\left[\begin{array}{cccc}
1 & \tilde{\mathrm{a}}_{12} & \ldots & \tilde{\mathrm{a}}_{1 n} \\
\tilde{\mathrm{a}}_{21} & 1 & \ldots & \tilde{\mathrm{a}}_{2 n} \\
\ldots & \ldots & 1 & \ldots \\
\tilde{\mathrm{a}}_{n 1} & \tilde{\mathrm{a}}_{n 2} & \ldots & 1
\end{array}\right]
$$

Accordingly, $\tilde{a}_{i j}$ is a TFN and when $\tilde{a}_{i j}=\mathrm{l}_{\mathrm{ij}}, \mathrm{m}_{\mathrm{ij}}$, $\mathrm{u}_{\mathrm{ij}}$, it is expressed as $\tilde{a}_{i j}=1_{\mathrm{ji}}, \mathrm{m}_{\mathrm{ji}}$, $\mathrm{u}_{\mathrm{ji}}$.

Step 2: The elements of the pairwise comparison matrices were calculated via the formula 5 below by using the geometric mean method suggested by Buckley [30]: 


$$
\tilde{a}_{i j}=\left(\hat{a}_{i j}^{1} \otimes \hat{a}_{i j}^{2} \otimes \ldots \otimes \hat{a}_{i j}^{n}\right)^{1 / n}
$$

Step 3: The $r_{i}$ value that is necessary for calculating the criteria weights was obtained using the following formula 6 :

$$
\hat{r}_{\mathrm{i}}=\left(\hat{a}_{i 1}^{1} \otimes \hat{a}_{i 2}^{2} \otimes \ldots \otimes \hat{a}_{i n}^{n}\right)^{1 / \mathrm{n}}
$$

Step 4: The formula 7 below was applied to calculate the weights of each criterion.

$$
\widehat{w}_{\mathrm{i}}=\hat{r}_{\mathrm{i}} \otimes\left(\hat{r}_{1} \oplus \hat{r}_{2} \oplus \ldots \oplus \hat{r}_{\mathrm{n}}\right)^{-1}
$$

Step 5: The values of the fuzzy PIS, FPIS $\left(\mathrm{A}^{+}\right)$, and the fuzzy NIS, FNIS $\left(\mathrm{A}^{-}\right)$, were determined using the following formulas 8 and 9:

$$
\begin{aligned}
& \mathrm{A}^{+}=\left(\tilde{v}_{1}^{+}, \tilde{v}_{2}^{+}, \ldots, \tilde{v}_{\underline{n}}^{+}\right) \\
& \mathrm{A}^{-}=\left(\tilde{v}_{1}, \tilde{v}_{2}, \ldots, \tilde{v}_{n}\right)
\end{aligned}
$$

where $v_{j}^{+}=\max \left\{v_{\mathrm{ij} 1}{ }^{+}\right\}$and $v j^{-}=\min \left\{\mathrm{v}_{\mathrm{ij} 1}{ }^{+}\right\}, \mathrm{i}=1,2, \ldots, \mathrm{m} ; \mathrm{j}=1,2, \ldots, \mathrm{n}$. Step 6: Each criterion's distance from FPIS and FNIS was calculated with the formulas (10) below:

$$
\begin{array}{ll}
\mathrm{d}_{1}^{+}=\sum_{j=1}^{n} \mathrm{~d}_{v}\left(\tilde{\mathrm{v}}_{i j}, \tilde{\mathrm{v}}_{j}^{+}\right) & \mathrm{i}=1,2, \ldots, \mathrm{m}, \\
\mathrm{d}_{1}=\sum_{j=1}^{n} \mathrm{~d}_{v}\left(\tilde{\mathrm{v}}_{i j}, \tilde{v}_{j}\right) & \mathrm{i}=1,2, \ldots, \mathrm{m}
\end{array}
$$

where $d_{v}(\ldots)$ is the distance between two fuzzy numbers.

Step 7: $\mathrm{CC}_{\mathrm{i}}$, which expresses the distance of the criteria from both the FPIS and FNIS simmultaneously, is defined as sorting alternatives from top to bottom. The $\mathrm{CC}_{\mathrm{i}}$ value of each criterion can be calculated using the following formula 11:

$$
\mathrm{CC}_{\mathrm{i}}=\frac{d_{i}^{-}}{d_{i}^{+}-d_{i}}, \quad \quad \mathrm{i}=1,2, \ldots, \mathrm{m} .
$$

Step 8: A ranking was made among the alternatives by scrutinizing the $\mathrm{CC}_{\mathrm{i}}$ values. Therefore, as the alternative $\mathrm{Ai}$ approaches 1, it will move closer to the FPIS and away the FNIS.

\section{Application}

In this section, prioritizing the proposed strategies to reduce air pollution from ships in and around of the Strait of Istanbul and the sensitivity level measurement of the ships passing through the strait by the hybrid fuzzy AHP-TOPSIS method were described step-by-step. Thus, the problem is expressed by emphasizing the special situation of the Strait of Istanbul. The competency levels of the experts whose opinions were taken for analyses were introduced and the application steps of the method described in the previous section for the solution of this problem were explained.

\subsection{Problem Description}

Air pollution is a major environmental problem threatening human health. The transportation sector, particularly maritime transportation, exhibits a significantly negative contribution to air pollution. For changing or at least limiting this situation, the IMO MARPOL Annex VI (1997) limited the use of fuels that cause a high rate of sulfur emissions. It allows the use of not more than $4.5 \%$ content of sulfur fuels worldwide and $1.5 \%$ in sulfur emission control areas (SECA). These restrictions, which were implemented for the first time in 2005, have been tighter over the years. According to the rules currently enforced, the ships cannot release more than $0.5 \%$ sulfur very-low sulfur fuel oil (VLSFO) worldwide and not more than $0.1 \%$ sulfur ultra-low sulfur fuel oil in SECA. However, these rules stated that the ships with scrubber systems can use low sulfur fuels (limited to $3.5 \%$ content of sulfur). These rules have made a significant change in the maritime sector and ship owners compete to comply with the rules more quickly. In addition to these strict rules, the IMO has developed major strategies for reducing emissions from the ships and developed basic strategies such as technical (e.g., low sulfur fuel use and on board pollutant abatement systems), operational (e.g., low speed and use of shore-based electricity in port), and market-based (e.g., providing some advantages to the green ships).

Although the implementation of IMO, which is enforced until the first of January 2020, is an essential step for reducing air pollution from ships in many regions with heavy vessel traffic, such as the Strait of Istanbul, this practice may not be enough. Considering the population density of Istanbul City, the impact area of air pollution in the Strait of Istanbul is becoming more serious. In this sense, even though the ships passing through the strait use VLSFO fuels, 0.5\% sulfur emissions are threatening the health of the people in the region. Besides, the high price differences between the LSFO and VLSFO and the expectations regarding the continuity of these price levels make the owners prefer the use of scrubbers. Monitoring of the usage of the scrubbers will be difficult, especially in open seas and in areas with heavy vessel traffic.

In this study, additional strategies have been proposed by considering the IMO and EU standards and the ship owner companies' applications to reduce the air pollution caused by the ships in and around the Strait of Istanbul. Table 3 lists these strategies and their definitions. The strategies were first prioritized by taking the experts' opinions and the sensitivity levels of the different ship types to these strategies were then measured. 
Table 3. Strategies to reduce air pollution in Strait of Istanbul and its definitions

\begin{tabular}{|c|c|c|c|c|}
\hline Code & Strategies & CL & Definitions & Example \\
\hline C1 & $\begin{array}{l}\text { Declaration of the Strait of } \\
\text { Istanbul and the Marmara } \\
\text { Sea as a Sulfur Emission } \\
\text { Control Area (SECA) }\end{array}$ & \multirow{4}{*}{ 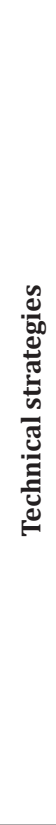 } & $\begin{array}{l}\text { It is stated that the Strait of Istanbul and the } \\
\text { Marmara Sea is declared as a SECA. The fuel sulfur } \\
\text { content to be used by the ships in this area should } \\
\text { not exceed } 0.1 \% \text {. }\end{array}$ & $\begin{array}{l}\text { IMO MARPOL 73/78 Annex VI-designated } \\
\text { emission control areas. More stringent } \\
\text { requirements are applied in these regions } \\
\text { compared to other waters (e.g., North Sea, Baltic } \\
\text { Sea, Caribbean Sea, and North America Sea). }\end{array}$ \\
\hline C2 & $\begin{array}{c}\text { Establishment of current } \\
\text { detection system }\end{array}$ & & $\begin{array}{l}\text { The establishment of the current detection and } \\
\text { forecasting system provides the ships with minimum } \\
\text { exposure to the counter current and maximum use } \\
\text { of the current toward the ship owing to the inclusion } \\
\text { of this information in the traffic-planning system. It } \\
\text { aims to reduce emissions by using the ship's engine } \\
\text { in the most effective way. }\end{array}$ & $\begin{array}{l}\text { The current speed distribution forecast system } \\
\text { that is used by NYK within the Kuroshio } \\
\text { current near the Taiwan Strait. The system was } \\
\text { confirmed to save } 9 \% \text { of fuel consumption [16]. }\end{array}$ \\
\hline C3 & $\begin{array}{l}\text { Prohibition of the use of } \\
\text { heavy fuel on ships }\end{array}$ & & $\begin{array}{l}\text { It emphasizes the prohibition of the use of heavy } \\
\text { fuels in the Strait of Istanbul and the Marmara Sea } \\
\text { and recommends the vessels to use marine gas oil } \\
\text { instead of heavy fuels when passing through these } \\
\text { areas. }\end{array}$ & $\begin{array}{l}\text { The Maersk Line began to switch its bunker to } \\
\text { low sulfur within } 24 \text { miles of California ports in } \\
2006 \text { [16]. }\end{array}$ \\
\hline C4 & $\begin{array}{l}\text { Monitoring of low sulfur } \\
\text { fuel usage with remote } \\
\text { detector systems }\end{array}$ & & $\begin{array}{l}\text { To monitor whether the current MARPOL Annex } \\
\text { VI requirements are being applied, drone detector } \\
\text { systems are to be placed under bridges. }\end{array}$ & $\begin{array}{c}\text { The project named, "Surveillance of sulfur and } \\
\text { particle pollution from ships," is co-financed by } \\
\text { the Danish Environmental Protection Agency, } \\
\text { which performs remote measurements in the } \\
\text { Great Belt Bridge. }\end{array}$ \\
\hline C5 & Optimizing speed limits & \multirow{4}{*}{ 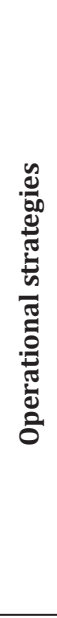 } & $\begin{array}{l}\text { Less emission is foreseen because of sailing at lower } \\
\text { speeds in the mentioned areas. }\end{array}$ & $\begin{array}{l}\text { Port of Los Angeles-Vessel Speed Reduction } \\
\text { Program (VSRP). }\end{array}$ \\
\hline C6 & $\begin{array}{l}\text { Reducing of waiting times } \\
\text { of ships }\end{array}$ & & $\begin{array}{l}\text { By reducing the waiting time of the ships in the } \\
\text { anchorage areas, the emissions during the waiting } \\
\text { period are foreseen to be reduced. }\end{array}$ & $\begin{array}{c}\text { A national action could be taken by the Turkish } \\
\text { government against air pollution near the Strait } \\
\text { of Istanbul according to IMO Res MEPC. } 304 \\
\text { (72)/Candidate short-term measures. }\end{array}$ \\
\hline C7 & $\begin{array}{l}\text { Updating the regulations } \\
\text { regarding the waiting } \\
\text { times in the anchorage } \\
\text { areas of the Strait of } \\
\text { Istanbul }\end{array}$ & & $\begin{array}{l}\text { In the current } 168 \text { hours of application, if additional } \\
\text { fees will be applied depending on the ship's staying } \\
\text { time in the anchorage areas, the waiting time of the } \\
\text { ships will reduce and will consequently decrease the } \\
\text { emissions. }\end{array}$ & $\begin{array}{c}\text { A national action could be taken by the Turkish } \\
\text { government against air pollution near the Strait } \\
\text { of Istanbul according to the IMO Res MEPC. } 304 \\
\text { (72)/Candidate short-term measures. }\end{array}$ \\
\hline C8 & $\begin{array}{l}\text { Encourage the use of a } \\
\text { pilot }\end{array}$ & & $\begin{array}{l}\text { With the use of a pilot's experience, it is thought } \\
\text { that the emissions will be reduced with the effective } \\
\text { use of the ship's engine power owing to minimum } \\
\text { exposure to counter current and maximum using of } \\
\text { the current toward ship. }\end{array}$ & $\begin{array}{l}\text { A national action could be taken by the Turkish } \\
\text { government against air pollution near the Strait } \\
\text { of Istanbul according to IMO Res MEPC. } 304 \\
\text { (72)/Candidate short-term measures. }\end{array}$ \\
\hline C9 & $\begin{array}{l}\text { Providing the use of } \\
\text { coastal electricity for all } \\
\text { ships in nearby ports }\end{array}$ & \multirow{3}{*}{ 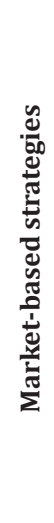 } & $\begin{array}{l}\text { It is foreseen that the emissions will be reduced } \\
\text { because of the use of coastal electricity by the } \\
\text { ships and cruising/passenger ferries in the ports of } \\
\text { Istanbul during the time they are alongside the pier. }\end{array}$ & $\begin{array}{l}\text { EU-COMMISSION RECOMMENDATION of } \\
\text { May 08, } 2006 \text { on the promotion of shore- } \\
\text { side electricity for use by ships at berth in } \\
\text { Community ports. Port of Kristiansand has } \\
\text { supplied shore power since } 2018 .\end{array}$ \\
\hline C10 & $\begin{array}{l}\text { Providing financial } \\
\text { advantages to ships } \\
\text { certifies that they are } \\
\text { doing green practices }\end{array}$ & & $\begin{array}{l}\text { Providing cost advantages to tolls for ships that } \\
\text { certify various additional green applications on air } \\
\text { pollution. }\end{array}$ & $\begin{array}{c}\text { The environmental ship index identifies a better } \\
\text { performance of ships in reducing air emissions } \\
\text { than the current emissions standards. Sweden } \\
\text { environmentally differentiated fairway dues } \\
\text { program. }\end{array}$ \\
\hline C11 & $\begin{array}{l}\text { Prioritizing direct passing } \\
\text { to the ships with certified } \\
\text { green application actions }\end{array}$ & & $\begin{array}{c}\text { This gives priority of transition to the ships that } \\
\text { certify that they are performing various applications } \\
\text { on air pollution. }\end{array}$ & $\begin{array}{c}\text { A national action could be taken by the Turkish } \\
\text { government against air pollution near the Strait } \\
\text { of İstanbul according to the IMO Res MEPC. } 304 \\
\text { (72)/Candidate short-term measures. }\end{array}$ \\
\hline
\end{tabular}


It is expected that the strategies in Table 3 can lessen the emission rates in the region. Peksen and Alkan [17] revealed that the emission rates in Istanbul City could drop by $53 \%$ if the region around the strait would be determined as SECA. Han [16] proposed the establishment of a current detection system and justified that NYK, one of the biggest ship owner companies, had exploited the "Kuroshio current" near the Taiwan Strait to save fuel consumption and indirectly reduce emissions. As a result of prohibiting the usage of heavy fuel oil (HFO) on ships, the Maersk Line started to use fuels with less than $0.2 \%$ sulfur content within 24 miles of the California port. Through this, the $\mathrm{SO}_{\mathrm{x}}$ and $\mathrm{NO}_{\mathrm{x}}$ emissions could be reduced by $95 \%$ and $12 \%$, respectively [16]. The port of Los Angeles has implemented the "optimizing speed limits" strategy since 2001 via its Vessel Speed Reduction Program, and with this, the EU [31] forecasted a reduction of $\mathrm{CO}_{2}$ emissions by $17 \%-34 \%$. "Cold ironing", which uses coastal electricity in ships, can decrease $\mathrm{CO}_{2}$, carbon monoxide, and nitrous oxide emissions by over $50 \%, 99 \%$, and $50 \%$, respectively, according to the report published in the Official Journal of the EU [32]. The Sweden Environmentally Differentiated Fairway Dues Program provides financial advantages to ships certifying that they are doing green practices, which aimed at decreasing the whole harmful emissions by about $75 \%$ [33].

\subsection{Identification of the Experts}

Pollution reduction strategies are intrinsically qualitative processes and it would be more appropriate to consult opinions from experts in identifying these strategies. To have a better understanding of these strategies, it is important to express the opinions of experts quantitatively on these qualitative strategies. This also requires careful selection of the most appropriate experts on this matter. All the selected experts are oceangoing masters, making it easier for them to estimate the effect levels of the related strategies. Their long service time adequately enables them to know the strategies applied in other international channels or straits. In this study, five experts were marine pilots, vessel traffic operators, and academicians. Four of them stay in the Strait of Istanbul as a marine pilot or vessel traffic operator and have at least 10 years work experience. One of them is a professor and had conducted studies on the ship emissions around the Istanbul City [34,35]. He was also assigned as the Head of Istanbul Metropolitan Municipality Department of Environmental Protection and Control. Table 4 presents detailed information about the selected experts, who were asked on which strategies stand out from the rest and which types of ships are more sensitive to these strategies.

\subsection{Application of the Methods}

Istanbul City is one of the most populated cities and has one of the heaviest maritime traffic owing to the Strait of Istanbul. This consequently increases air pollution and thus requires urgent actions. As a solution, this study proposed strategies for reducing air pollution from ships passing the Strait of Istanbul. First, the priority levels of these strategies were analyzed via the fuzzy AHP method by receiving the experts' opinions. The analysis results (Table 5) determined the overcome power of the implementation of each strategy.

As shown in Table 5, C1 (Declaration of the Strait of Istanbul and the Marmara Sea as a SECA) was seen as the highest priority strategy to reduce the air pollution from shipping activities in the region. As known, ships cannot release more than $0.1 \%$ sulfur in SECA, which can result in quality fuel consumption around Istanbul City, tending the experts to prefer this option. C3 (Prohibition of the use of HFO on ships) had become the second highest priority strategy, which can be associated with the highest priority strategy. The experts turned to direct, effective strategies in their selection to reduce air pollution. The C4 strategy (Monitoring of low sulfur fuel usage with remote detector systems) follows

Table 4. General information of the experts

\begin{tabular}{|c|c|c|c|}
\hline $\begin{array}{c}\text { Expert } \\
\text { number }\end{array}$ & Current job & Adequacy & $\begin{array}{c}\text { Current work } \\
\text { experience }\end{array}$ \\
\hline Expert-1 & Marine pilot & $\begin{array}{c}\text { Oceangoing } \\
\text { master }\end{array}$ & 13 years \\
\hline Expert-2 & Marine pilot & $\begin{array}{c}\text { Oceangoing } \\
\text { master }\end{array}$ & 13 years \\
\hline Expert-3 & Marine pilot & $\begin{array}{c}\text { Oceangoing } \\
\text { master }\end{array}$ & 14 years \\
\hline Expert-4 & Academician & Professor & 5 years \\
\hline Expert-5 & $\begin{array}{c}\text { Vessel traffic } \\
\text { operator }\end{array}$ & $\begin{array}{c}\text { Oceangoing } \\
\text { master }\end{array}$ & 10 years \\
\hline
\end{tabular}

Table 5. Weights of dimensions and criteria for decision-making groups

\begin{tabular}{|c|c|c|}
\hline Criteria & Fuzzy weight & Rank \\
\hline C1 & $(0.147,0.146,0.138)$ & 0.144 \\
\hline C2 & $(0.071,0.068,0.068)$ & 0.069 \\
\hline C3 & $(0.135,0.137,0.133)$ & 0.135 \\
\hline C4 & $(0.114,0.113,0.108)$ & 0.112 \\
\hline C5 & $(0.076,0.076,0.076)$ & 0.076 \\
\hline C6 & $(0.078,0.077,0.078)$ & 0.078 \\
\hline C7 & $(0.072,0.072,0.073)$ & 0.072 \\
\hline C8 & $(0.071,0.075,0.079)$ & 0.075 \\
\hline C9 & $(0.09,0.092,0.097)$ & 0.093 \\
\hline C10 & $(0.07,0.068,0.071)$ & 0.070 \\
\hline C11 & $(0.075,0.076,0.079)$ & 0.076 \\
\hline
\end{tabular}


C3 where the experts emphasized that standardizing and controlling applications that improve fuel quality is as important as improving the fuel quality. Alternatively, C8 (Encourage the use of pilot), C5 (Optimizing speed limits), and C7 (Updating the regulations regarding waiting times in the anchorage areas of the Strait of Istanbul) were perceived as important as much as others. However, they were blended in the experts' direct outcome-oriented evaluations.

The selected vessel types for this study are as follows: (1) direct passing ships, (2) calling ships (ships that stay in ports for a while), and (3) ferries. The sensitivity level of these ships to the abovementioned strategies were analyzed by the fuzzy TOPSIS method. The analysis showed that the direct passing ships had the highest sensitivity level to the strategies held in this study according to the selected experts (Table 6). The direct passing ship's CC score is more than twice that of the ferries. The second highest sensitivity level was achieved by the calling ships vessel type with a slightly lower CC score than that of the direct passing ships. Finally, the ferries exhibited the lowest sensitive vessel type to the strategies among the vessels passing through the Strait of Istanbul.

\subsubsection{Case Study}

Istanbul City is one of the largest cities of the region with the following shipping activities: (1) vessels stopped over in ports, (2) vessels passing without stopover, and (3) local maritime traffic. These contribute to air emissions, which pose a threat to the environment. Sixteen port facilities have given service in Istanbul City, but the ports are not solely responsible for dense sea traffic in the city. Istanbul City also has the Strait of Istanbul, which is 17 nautical miles long and with an average of 55,000 ships passing every year, making it a unique waterway in the region. Approximately 150 ships pass through the Strait of Istanbul every day, of which 27-28 ships carry dangerous goods. The Strait of Istanbul has 2,500 local maritime traffic transporting approximately $2,000,000$ people. Besides physical, oceanographic, and meteorological elements that restrict the safety sailing in the channel, the Strait of Istanbul is four times denser than the Panama Canal (in terms of the number of ships passing) and has three times heavier traffic than the Suez Canal.

After the analyses, some interesting findings particular to Istanbul City had been obtained. The "Declaration of the Strait of Istanbul and the Marmara Sea as a SECA" had

Table 6. The fuzzy evaluation of "CC" results

\begin{tabular}{|c|c|c|c|c|}
\hline Vessel type & d+ & d- & CC & Rank \\
\hline Direct passing ships & 1.292 & 3.025 & 0.701 & 1 \\
\hline Calling ships & 1.760 & 2.525 & 0.589 & 2 \\
\hline Ferries & 2.860 & 1.414 & 0.331 & 3 \\
\hline
\end{tabular}

been seen as the most important strategy to reduce the air pollution in Istanbul City. Within the scope of the IMO 2020 restrictions, the IMO determined several marine areas as SECA, which do not include the Strait of Istanbul. If the Istanbul City were to be recognized as a SECA, there would be a quantum jump to increase fuel quality and accordingly reduce the air pollution around the city. Finally, it is revealed that the direct passing ships that pass through the strait via the 16 port facilities located in Istanbul City have the highest sensitivity level to the protective strategies. In Istanbul City, the number of direct passing ships that passes the ports is greater than the number of ships that stay in ports for a while owing to the strategic mission of the strait in the world trade. Nevertheless, the ships' waiting times before passing have been increased from 48 to 168 hours. As a result, the direct passing ships stay around the Istanbul City longer than the calling ships. This situation may increase the sensitivity level of direct passing ships passing through the Strait of Istanbul to the proposed strategies more than the different marine areas in the world.

\section{Discussion}

Han [16] recognized the emissions from oceangoing vessels as one of the major sources of air pollution in the shipping industry. After the author had presented the ships' negative contribution to air pollution, IMO precautions against air pollution from ships were evaluated. Finally, emission mitigation strategies were revealed. Alternatively, Wang et al. [27] proposed strategies to reduce air pollution from ships similar to Han [16]. Additionally, they stated historical developments of these strategies and regional actions against air pollution. In this study, the strategies against air pollution from vessels that were expressed in previous studies and the reports of IMO and EU were collected. Moreover, new regional strategies particular to the Strait of Istanbul were added to the evaluation. The strategies' priority levels specific to the Strait were then analyzed. Finally, the sensitivity levels of different vessel types passing through the Strait to these strategies were determined. As a contribution, this study is the only study that uses an approach to preventive strategies against air pollution from ships in terms of priority perception for the Strait of Istanbul. Additionally, this study is also a unique study that evaluated the adaptation potential level of ships to strategies mitigating air pollution.

Ünlügençoğlu et al. [34] and Ünlügençoğlu and Alarçin [35] estimated emissions that contributed to air pollution around the region of Ambarl Port, which is the biggest port facility in İstanbul and also one of the biggest ones in Turkey. Alternatively, Dogrul et al. [12] calculated $\mathrm{SO}_{2}$ 
emissions caused by the ships passing through the Strait of Istanbul by performing measurements for unsteady and steady cases. They also made short-term predictions by considering different scenarios. Lastly, Bayırhan et al. [11] tried determining the exhaust gas emissions of the ferries passing through the strait. Their proposed model is based on the actual ferry movements and ferry machinery information. The proposed model of this study involved both oceangoing and local vessels. Furthermore, this study has a typical study area compared with others and estimated the sensitivity level of each ship type passing through the strait to aforementioned strategies.

\section{Conclusion}

The studies on air pollution have substantially increased recently. The most important reason for this increase is that environmental degradation such as global warming and climate changes have become more visible. In addition, the impact of the transportation sector on air pollution is at a considerable level. The share of maritime transport in the global transport industry is much higher than other modes. In this context, the maritime transport sector contributes negatively to air pollution, especially via vessels. In accordance with all these parameters, it has become necessary to take precautions for air pollution caused by marine vessels. For this purpose, the IMO, which is the umbrella organization of the maritime sector, has introduced regulations called "IMO 2020". In addition to these regulations, the EU has developed certain strategies. Private companies are working day-to-day to comply with these regulations and strategies.

In this study, the strategies to reduce the air pollution that threatens human health were approached across the Strait of Istanbul, which affects densely populated areas. Relevant strategies were determined considering the standards set by IMO and EU. These strategies and alternatives were evaluated by selected experts who are employed as a marine pilot, a vessel traffic operator in the Strait of Istanbul, or an academician with studies on ship emissions. These evaluations were expressed mathematically using the fuzzy AHP-TOPSIS hybrid method. Based on the results, C1 (Declaration of the Strait of Istanbul and the Marmara Sea as a SECA), C3 (Prohibition of the use of HFO on ships), and C4 (Monitoring of low sulfur fuel usage with remote detector systems) were the predominant strategies, which show that the experts approached the problem in a realist way and emphasized the strategies related to the use of high-quality fuels as an exact solution. However, C8 (Encourage the use of pilot) and C7 (Updating the regulations regarding waiting times in the anchorage areas of the Strait of Istanbul) were ignored by the experts. Accordingly, it can be concluded that the use of a marine pilot will not adequately reduce the use of the main engine, and the emissions made by the ships through the auxiliary machine while waiting at anchor are not considered remarkable. In line with the strategies prioritized by the experts, the direct passing ships were determined as the most sensitive alternative to these strategies. Since the calling ships and ferries do not use heavy fuels while maneuvering along the strait, they are observed to be less affected by the related strategies than the direct passing ships. Moreover, the direct passing ships use their main engines more than the others during their stay around Istanbul City. Thus, the restrictions of the proposed strategies directly affect the direct passing ships, and their sensitivity levels accordingly increase.

These results develop a perspective for the Strait of Istanbul concerning the air pollution that stems from the vessels. Relevant strategies and alternatives provide a basic perspective for further studies. New studies can be produced by updating the number of alternatives, strategies, and experts or by comparing them with other methods (e.g., fuzzy VIKOR, PROMETHEE, and ELECTRE).

\section{Authorship Contributions}

Concept design: U. Bucak, T. Arslan, H. Demirel, A. Balın, Data Collection or Processing: U. Bucak, T. Arslan, H. Demirel, A. Balın, Analysis or Interpretation: U. Bucak, T. Arslan, H. Demirel, A. Balın, Literature Review: U. Bucak, T. Arslan, H. Demirel, A. Balın, Writing, Reviewing and Editing: U. Bucak, T. Arslan, H. Demirel, A. Balın.

Funding: The authors declared that this study received no financial support.

\section{References}

[1] M. R. Brooks, and P. Faust, "50 years of Review of Maritime Transport, 1968-2018 Reflecting on the past, exploring the future," Geneva: UNCTAD Publishing, 2018, pp. 1-86.

[2] A. Parker, and D. Namuth-Covert, "International Plant Protection Convention (IPPC)" Protecting the World's Plant Resources from Pests, Rome: 2014.

[3] L. Zhen, D. Zhuge, L. Murong, R. Yan and S. Wang, "Operation management of green ports and shipping networks: Overview and research opportunities" Frontiers of Engineering Management, vol. 6, pp. 152-162 Apr 2019.

[4] European Union. "Integrating Maritime Transport Emissions in the EU's Greenhouse Gas Reduction Policies: European Commission" Brussels: Publications Office of the European Union, 2013. https://www.iea.org/policies/8790-integratingmaritime-transport-emissions-in-the-eus-greenhouse-gasreduction-policies

[5] A. Armellini, S. Daniotti, and P. Pinamonti. "Gas turbines for power generation on board of cruise ships: a possible solution 
to meet the new IMO regulations?" Energy Procedia, vol. 81, pp. 540-547, Dec 2015.

[6] IMO. "Air Pollution and Energy Efficiency" London: IMO Publishing, 2016. http://pure .iia sa.ac.at/id/eprin t/13467/1/ WorldEn er gyOut lookSp ecialReport201 6EnergyandAirP oll ution.pdf

[7] O. N. Kara, "Air Pollution in Istanbul." Hague: Netherlands Enterprise Agency, 2018.

[8] Türklim. Turkish Port Sector Report, Istanbul: Türklim Publishing, 2019.

[9] MTI, Atlantis, "Turkish Maritime Trade Statistics," 2019. [Online]. Available: https://atlantis.udhb.gov.tr. [Retrieved: December 20, 2019].

[10] Istanbul Port Authority (2018). Local Marine Traffic Guide. Istanbul: Istanbul Port Authority.

[11] İ. Bayırhan, K. Mersin, A. Tokuşlu, and C. Gazioğlu, "Modelling of ship originated exhaust gas emissions in the Strait of Istanbul (Bosphorus)," International Journal of Environment and Geoinformatics, vol. 6, pp. 238-243, Dec 2019.

[12] A. Doğrul, Y. A. Ozden, and F. Celik, "A numerical investigation of $\mathrm{SO}_{2}$ emission in the Strait of Istanbul," Fresenius Environment Bulletin, vol. 25, pp. 5795-5803, Dec 2016.

[13] U. Im, et al. "The impact of anthropogenic and biogenic emissions on surface ozone concentrations in Istanbul," Science of the Total Environment, vol. 409, pp. 1255-1265, Mar 2011.

[14] A. Kılıç, “Marmara Denizi'nde gemilerden kaynaklanan egzoz emisyonları." Balıkesir Üniversitesi Fen Bilimleri Enstitüsü Dergisi, vol. 11, pp. 124-134, 2016.

[15] N. Öztürk, and E. Y. Küçükgül, "Deniz ticareti ve limanlardan kaynaklanan hava kirliliğinin önlenmesi ve MARPOL Ek VI." Hava Kirliliği ve Kontrolü Ulusal Sempozyumu, 655-669 Ekim 2008.

[16] C. H. Han, "Strategies to reduce air pollution in shipping industry," The Asian Journal of Shipping and Logistics, vol. 26, pp. 7-29, Jun 2010.

[17] D. Y. Peksen, and G. Alkan, "Economic and environmental contributions of declaration of the Marmara region as Emission Control Area (ECA)," IOSR Journal of Engineering, vol. 6, pp. 4757, Jul 2016.

[18] V. Raţa, C. Gasparotti, and L. Rusu, "The importance of the reduction of air pollution in the Black Sea basin," Mechanical Testing and Diagnosis, vol. 7, pp. 5-15, July 2017.

[19] V. Tatar, and M. B. Özer, "The impacts of $\mathrm{CO}_{2}$ emissions from maritime transport on the environment and climate change" Uluslararası Çevresel Eğilimler Dergisi, vol. 2, pp. 5-24, 2018.

[20] A. Balin, H. Demirel, and F. Alarcin, "A novel hybrid MCDM model based on fuzzy AHP and fuzzy TOPSIS for the most affected gas turbine component selection by the failures," Journal of Marine Engineering \& Technology, vol. 15, pp. 69-78, Jul 2016.

[21] G. Çakıroğlu, B. Şener, and A. Balin, "Applying a fuzzy-AHP for the selection of a suitable tugboat based on propulsion system type" Brodogradnja: Teorija I Praksa Brodogradnje I Pomorske Tehnike, vol. 69, pp. 1-13, 2018.

[22] C. K. Kwong, and H. Bai, "A fuzzy AHP approach to the determination of importance weights of customer requirements in quality function deployment," Journal of Intelligent Manufacturing, vol. 13, pp. 367-377, Oct 2002.

[23] C. Kahraman, V. Cebeci, and D. Ruan, "Multi-attribute comparison of catering service companies using fuzzy AHP: the case of Turkey," International Journal of Production Economics, vol. 87, pp. 171-184, Jan 2004.

[24] O. Durán, and J. Aguilo, “Computer-aided machine-tool selection based on a Fuzzy-AHP approach," Expert Systems with Applications, vol. 34, pp. 1787-1794, Apr 2008.

[25] H. K. Chiou, and G. H. Tzeng, "Fuzzy hierarchical evaluation with grey relation model of green engineering for industry," International Journal of Fuzzy System Applications, vol. 3, pp. 466-475, Jan 2001

[26] Y. P. Jiang, and Z. P. Fan, "A practical ranking method for reciprocal judgment matrix with triangular fuzzy numbers," System Engineering, vol. 20, pp. 89-92, Aug 2015. [Online]. Available: https://www.tandfonline.com/loi/tmar20 [Accessed Sept. 17, 2016].

[27] J. W. Wang, C. H. Cheng, and K. C. Huang, "Fuzzy hierarchical TOPSIS for supplier selection," Applied Soft Computing, vol. 9, pp. 377-386, Jan 2009.

[28] C. L. Hwang, and K. Yoon, Multiple Attributes Decision Making Methods and Applications, Berlin: Springer, 1981.

[29] I. Ertuğrul, and N. Karakașoğlu, "Comparison of fuzzy AHP and fuzzy TOPSIS methods for facility location selection," The International Journal of Advanced Manufacturing Technology, vol. 39, pp. 783-795, 2008.

[30] J. J. Buckley, "Ranking alternatives using fuzzy numbers," Fuzzy Sets and Systems, vol. 15, pp. 21-31, Feb 1985.

[31] European Union, "Time for International Action on $\mathrm{CO} 2$ Emissions from Shipping," Brussels: European Commission Publications Office of the European Union, 2013.

[32] European Union, "Official Journal of the European Union," Brussels: European Commission Publications Office of the European Union, 2006.

[33] T. Lindé, and I. Vierth, An evaluation of the environmentally differentiated fairway dues in Sweden 1998-2017, Stockholm: Statens Väg-Och Transportforskningsinstitut, 2018.

[34] K. Ünlügençoğlu, G. Kökkülünk, and F. Alarçin, "Estimation of shipping emissions via novel developed data collecting and calculation software: a case study for the Region of Ambarli Port," International Journal of Global Warming. vol. 19, pp. 293307, 2019.

[35] K. Ünlügençoğlu, and F. Alarçin, "The assessment of air quality in the Port of Ambarlı and several districts of Istanbul," International Journal of Global Warming, vol. 20, pp. 80-91, 2020. 